\title{
Culinary Caribbean English Lexicon in Panamanian Spanish
}

\author{
Martín Jamieson \\ Buenos Aires
}

\begin{abstract}
An offshoot of Caribbean Creole English, Panamanian Creole English has been the source of loanwords referring to culinary delicacies of West Indian origin in the officially Spanish-speaking Republic of Panama, whose main language has, in turn, influenced the Creole, though not only with words describing edibles. Most of the Creole English words seemed marginal before the middle of the twentieth century, but, by its end, had integrated Panamanian Spanish, along with lexical items from other languages, of which culinary forms are presented here side by side with patrimonial Spanish foodstuff terms of use in Panama.
\end{abstract}

\section{Panamanian Creole English}

It has been said that Panama - a crossroads for the Americas, and even the world - is also a melting pot. Items — "worter und sachen" — of this mixture have been borrowed from the English-speaking Caribbean into Panamanian Spanish. This paper ferrets out several culinary terms of West Indian Creole English provenance in contemporary Panamanian Spanish and remounts to their source. It also includes other words relating to food of differing origins current on the Isthmus, and points to items of Panamanian Spanish now used in the West Indian English varieties of the Republic. Spanish loanwords in Caribbean Englishes pose a problem for lexicographers, tourists, writers and readers of Caribbean literature (see Allsopp, J. 1996: 262-265). Caribbean English 
loanwords do as much for similar groups dealing with Panamanian Spanish. These pages contribute to their understanding.

Although the English-speaking West Indian community, in the view of the scientific observer, has been, for some time, one of the several components of the Panamanian population (today a total of over three million inhabitants scattered in, roughly, 75,000 square kilometers in the Central American republic, of whom descendants of West Indians represent over 100,000), sociopolitical issues have sometimes denied the group this status, and even the scope of its importance in Panamanian culture. This explains the limited number of studies published on this minority group in Panama, in general, and the relative absence of those of a linguistic nature in particular, for few linguistically skewed publications exist (see Jamieson 2004; p. 175 adds to Jamieson 1993). ${ }^{1}$

As of the nineteenth century, two major dialects of English have been continuously but (geographically and numerically considered) spoken in Panama, along with several minority Amerindian languages of long standing (Chocó, Dule, Naso or Ngöbe, Teribe and Waunana), Spanish (the official and majority language, introduced in the sixteenth century), other European languages and even Japanese, Hindustani and Chinese, the latter ones being of negligible importance considered in the whole.

The two major English dialects mentioned above are American English and Caribbean English, both in sundry geographical and social varieties. The American English dialects, whatever their nature, have usually been considered prestigious among West Indians and their Panamanian descendants, despite the fact that some of them may be the subject of disrepute in the United States. They have also been held in high esteem by the other Panamanians, independent of their mother tongue. ${ }^{2}$ The Caribbean Englishes, due to their close contact and interchange on the Isthmus, have coalesced into an overwhelmingly Jamaican-based Creole English continuum that can rightfully be termed Panamanian (Creole) English (henceforth, PCE), a brand in which the parenthetical word points not only to the historical origin, but also to the fact that most of its speakers habitually use PCE as a vernacular, for standard varieties are limited in functions. As reported by Justavino (1975), standard varieties have been, in many cases, intentionally taught to offspring, as opposed to having been spontaneously acquired.

The two major West Indian English-speaking groups to enter Panama for the construction of the isthmian waterway were of Barbadian and Jamaican origin. By the end of the twentieth century, Jamaican English was predominant. It is the proven base for PCE as it can be described today, although PCE has also been influenced by the speech varieties of a number of AfroCaribbean islands, both English- and Frenchspeaking.

PCE has been in an evident process of decreolization. This is also the case of the neighboring Limon Creole, from Costa Rica, which has a similar origin. However, Limon Creole seems to have been less subjected to the constant pervasive influence of North American English, and may have been less admixtured with non-Jamaican varieties (see Herzfeld 2002). ${ }^{3}$ 
A word on the geographic dialects of PCE seems appropriate. Four of them can be pointed out on the contemporary scene. These are

(a) the Puerto Armuelles dialect (southwestern province of Chiriquí);

(b) the (northwestern province of) Bocas del Toro dialect (along with the former variety, the most heavily creolized and the least prestigious);

(c) the (province of) Colón dialect, and

(d) the (province of) Panama dialect, centered on the capital city, the most decreolized of all.

These PCE varieties have had a greater or lesser influence on Panamanian Spanish and the latter has had effects on PCE.

\section{Panamanian Spanish loanwords in PCE}

Leticia C. Thomas-Brereton, in her 1993 edition of a Dictionary of Panamanian English, mentions a number of Hispanisms current in PCE (see the 'Appendix'). Those appearing in her dictionary are borrowings "deemed necessary for communication in the Creole" (p. 8). Hispanisms related to food are the following: ${ }^{4}$ biril 'a variety of bread'; chayote 'sechium edile' eaten as a vegetable'; chiicha 'a drink made from fresh fruit'; chicharóng 'deep fried pork rind'; duuro 'flavored ices frozen in small cups or ice cube trays'; eskoviich 'pickled fish, also known as skaviich fish' [this loanword seems pan-Caribbean, and may have been brought to Panama rather than learned in the country; see $D C U$, s.v.]; flauta 'a variety of bread'; fritura 'fried foods such as yuca, carimañolas, patacones, hojaldas, etc.'; guacho 'soupy meal made of rice, meat and vegetables'; guana 'large green edible lizard'; guandú 'peas from the Cajanus Cajan, also known as gungu peas or pigeon peas in the Caribbean'; karimañola 'deep-fried yuca dough filled with beef'; konkolón 'rice that remains stuck to the bottom of the pot, considered a delicacy'; mangotín 'a variety of plum also called Jew plum'; miicha bred 'a variety of bread'; ñampí 'one of the edible roots'; ohalda 'fried flour dough, often eaten for breakfast'; paleta 'frozen flavored ice on a stick'; papaya 'fruit of the Carica papaya, known elsewhere as paw-paw but, known as papaya in the U.S.'; patacon(es) 'slices of fried green plantains'; pecho 'bony part of beef used for soup'; piivá 'small, red or orange fruit of a palm tree. Must be boiled to be eaten'; rapaduuro 'cake of hardened cane sugar wrapped in banana leaves. Used for sweetening drinks'; raspao 'syrup over a cone of shaved ice sometimes served with honey and condensed milk topping'; rekao berde 'fresh herbs and vegetables used for seasoning foods'; skabiish 'pickled fish'; tamal(es) 'steamed ground corn, stuffed with chicken or pork and wrapped in banana leaves'; ${ }^{5}$ tortilla 'deep-fried ground corn patties'; yuuká 'Cassava root'.

\section{PCE loanwords in Panamanian Spanish}

The Bocas del Toro variety of PCE has been so pervasive and has so strongly influenced the Spanish of multilinguals of the province's coastal region, that an alarmed 
observer at some point feared that Spanish was disappearing from the area (see Cedeño Cenci 1960). A Caribbean Creole interjection of impatience or rejection, cho, assessed as of African origin (DJE, s.v.: 'Cho /cho, cha, chu, chot/ interj; ... perh < Ewe ... or Twi ...'), is frequent among even Spanish-speaking monolinguals in the area, to the point of their being stereotyped by its use.

Since the coastal and island regions of Bocas del Toro accepted a large influx of West Indians, English place names in the area have been predominant, and government intervention has aspired to eradicate them (Pereira de Padilla 1974: 67-69).

Panamanian Spanish of the Colon area includes many loanwords of PCE origin. Of those listed by Revilla (1982) as of the Caribbean city of Colon, bon, chatcotear (< short cut, amalgamated and made a verb using the Spanish -ear verb ending) and saril are current in the Spanish of Panama City. Others, such as bitopiá $<$ Eng. beat up $+\mathrm{Sp}$. verb ending -ear > -iar; bradá $\sim$ bredá < Eng. brother; liquiboia < Eng. little boy and yacró < John Crow, also from the city of Colón, are used elsewhere.

The speech of Panama City, the capital, includes forms that have naturally become general in the whole Republic: canyac < Caribbean English ganja, parna < Eng. partner, pasiero (also parsiero) < Jamaican English pasiero $^{6}(<\mathrm{Sp}$. pasajero according to the DJE). They appear in B. Isaza Calderón and R. J. Alfaro's Panameñismos, s.v., proof of their extensive use.

The American English varieties and the Caribbean Englishes evidently share a large number of phonemic, grammatical and lexical features. But, inasmuch as they differ, it is possible to attribute loanwords in Panamanian Spanish to either American English or the Caribbean Englishes. Such is the case of Caribbean English items such as batty (and its derivatives, as in batty boy or batty man 'homosexual', extended by gay culture towards the end of the twentieth century in the English-speaking world), bax, bieks, buai, calalú, domplín, ginal, sarril, souse, suití, wapy, waapin, wipindoun, all evidently of West Indian origin, due to their particular features.

To ascertain the origin of a form, the observer must pinpoint the (linguistic or extralinguistic) differences existing between the two major geographical varieties (American or West Indian). Thus, suití (stress on the last syllable, a frequent occurrence in disyllables in Caribbean English, as opposed to standard American or British English) or batisona (< Jamaican English batty + Spanish suffix -ona referring to female gender and large size) are evident loans from Caribbean English. In reference to suití, it should also be noted that the form sweet is mostly British, whereas candy is mostly American. ${ }^{7}$

The item calalú - Phytolacca icosandra -, with alternative spellings, referring to a vegetable of African origin, and the name of different dishes in the insular or mainland Caribbean in which a leafy green vegetable is included, was once common in Panama among Antilleans, but has fallen into disuse in the city of Panama and its adjoining regions. The preeminent Panamanian writer, Rogelio Sinán, uses calalú for local color without establishing its meaning in a 1946 short story dealing with anti-West Indian racism entitled "Todo un conflicto de sangre" (1971: 110). ${ }^{8}$

Another word, cabanga 'a type of biscuit; and, also, metaphorically, homesickness', general and of long standing in Panamanian Spanish (see Isaza Calderón and Alfaro 1968: s.v. and J. Edwards 1974: 10), has been traced back to West Africa; but so far no 
writer has suggested that it penetrated Panamanian Spanish through Caribbean English, though this may be the case (Edwards 1974: 10).

Forms other than the above have been listed as loanwords from PCE in Panamanian Spanish. Thomas-Brereton (2001: 78) has included the following as "lexical items that are readily understood in Panamanian Spanish" (the spelling is Thomas-Brereton's): bushí $<$ bushy, ${ }^{9}$ gyal < girl, jómpi-jómpi < jump, nait-a-fon < night of fun, regé < reggae, and uan pat $<$ one pot.

The DJE explains of jump, s.v., that it is 'vb dial. To dance with the jigging, up-anddown motion characteristic of African dancing, and, lately, of Revivalist and POCOMANIA meetings'. In Panama, these revivalist cults "with ancestral spirit-possession" are known, derogatively, as "jump up". Thomas-Brereton (1993: s.v.) defines this expression as 'applied to the Pentecostal religion and its followers' — or "jómpi-jómpi", defined by her as an adjective 'relative to or one who practices a religion that encourages its followers to jump, sing and talk in tongues during the religious service' (Thomas-Brereton 1993: s.v.). ${ }^{10}$ The $D C U$ doesn't register the religious meaning under jump or similar words. Its jump-up is a Carnival dance. Higuero Morales (1993: s.v.) spells the form yompi-yompi, and defines it imprecisely as 'Persona perteneciente a grupos no católicos'.

Higuero Morales also lists other words in Panamanian Spanish as of Caribbean origin. He proposes the following: Batí, boay (< boy), Colón buay, naitafón, ras (< Jamaican raas), rasbuai, rasta, rastabuay, saril, waping (< what happened?). The latter erroneously appears in Revilla (1982) as limited to the Atlantic city of Colón.

English place names of West Indian origin have been common in the coastal region of the province of Bocas del Toro, even though a State-initiated law to change them for Spanish forms was enacted many years ago. A list of almost forty of these can be read in Cedeño Cenci (1960: 30-31) or in Pereira de Padilla (1974: 68-69).

\section{Culinary terms proper}

According to Thomas-Brereton, "Panamanians in the general population enjoy AfroAntillean foods" (2001: 78) which makes the existence of food-related lexical items easily explainable. Her statement is independently corroborated by César Young Núñez, the Panamanian chronicler and poet, who, quoting a countryman, wrote that, at a certain nightspot, one could find that "además del bofe picado, había morcillitas, domplín con bacalao y las empanadas patí que son un emblema de la maravilla culinaria de la cocina antillana" (Young Núñez 2005: 83).

Celestino Andrés Araúz Monfante, a major Panamanian historian, native to the Caribbean province of Bocas del Toro, referring to his home region, where, in its coastal sections, West Indian influence is paramount, validated Thomas-Brereton's assertions in the following extended quotation (in which citations have been eliminated):

La llegada de los antillanos también provocó transformaciones en la dieta, las bebidas, la casa habitación y las diversiones de los habitantes de la región. El arroz con pollo fue reemplazado por el rice n' beans [also known as rice an' peas], el 'guaro' por el ron... 
Fue en el campo de la alimentación donde los criollos [descendants of West Indians] impusieron con mayor energía su dieta por encima de la de indígenas e hispanos que terminaron, en muchos casos, por adoptar sus ingredientes y recetas. El desayuno, a las 7.30 a.m., consistía en té o chocolate y pan, generalmente sin leche, que se usaba poco, aunque la gente pobre consumía leche de coco. Al mediodía en el almuerzo predominaba el pescado adobado, frito, hervido o en "rondón". También se comía carne de tortuga adobada, en tanto que los puercos y las reses eran excepcionales. La gente criaba gallinas pero pocas veces las sacrificaba para comerlas y las reservaba para la Navidad. El arroz era indispensable en la mesa, al igual que los plátanos, las yucas y las patatas, mientras que los vegetales no formaban parte de la dieta diaria. [......] Una de las bebidas más populares entre los criollos era la "mishia" o "mogo" que se hacía hirviendo un guineo verde con azúcar.

Los criollos consideraban que la comida de los indígenas era sosa porque carecía de condimentos: 'todo lo hierven añadiéndole sal después que lo sacan del agua caliente'. (Araúz Monfante 2007: 177-178)

The "indígenas" of bland taste were the ngöbe-buglés. The cuisine of the "hispanos" group, however, had a certain degree of variety in it. Luisita Aguilera Patiño, in her El panameño visto a través de su lenguaje (pp. 80-95), notes traditional dishes and beverages: rice, a staple in Panama as well as in several Caribbean regions, in many forms and dishes (arroz con cabo de tabaco, arroz con cacao, arroz con coco, arroz con dulce, arroz fututiao, gallo pinto, guacho, guachito caldeado, rancho de frijoles, sancocho); also, other edibles were angú, atolito, bienmesabe, bizcochuelos, bollo, buñuelos pícaros, cabanga, cabellito de ángel, cafongo, carimañola, carne en pelota, chicha, chicheme, chilate, chupe, cocada, cochifrito, empanada, gladiola, gollerías, guineo o plátano paso o pasao, guisado, huevitos de faltriquera, manjar blanco, melcocha, mojón de perro, niños desnudos, raspadura, ropa vieja, pesá, patacones, resbaladera, sopa borracha, suripico, tamal, topetones, and torta. Most of these are still part of the contemporary Panamanian menu, which has gathered other additions.

Pointedly referring to the demonstration effect of the American presence in the former Panama Canal Zone, an American-run enclave existing between 1904 and 1999, Porcell (1976: 9) writes that at the coming of the North Americans "el anisado, el guarapo de caña fermentado y el aguardiente" — along with rum — were common alcoholic beverages, later partially replaced by beer and whisky, and that the following foodstuff predominated:

La cultura del maíz dominaba y sigue pesando en la diaria merienda panameña. La tortilla y el bollo, en sus múltiples variantes; la pata de ñopo o la mazamorra de maíz nuevo; el pan de maíz o los alfajores, conformaban una cultura culinaria, tramada en la naturaleza y la historia primitiva de nuestro pueblo.

Los tasajos de carne de res o puerco, junto con los frijoles y el café, complementaban una ración autóctona, que de vez en cuando se combinaba con carne de zahino [sic], conejo o venado. Y junto a todo esto los quimbolitos, los guachos, la yuca, el ñame, el otoe, y la culminación gustativa en el tradicional sancocho de gallina. 
¡Ah, la dulcería de nuestros antepasados! Los suspiros, los huevitos de fladriquera [sic; others also call them "de faldiquera"], la cabanga, las cocadas y el mielmesabe [sic; others say bienmesabe], para mencionar sólo algunas artesanías postergadas, se degustaban con un sentido de lo que es propio y originariamente gustado. (Porcell 1976: 9)

As of the beginning of the twentieth century, a number of traditional meals were replaced by others from different countries (China, France, Italy, the United States), nudging the Panamanian palate (above all, that of the capital, Panama, and that of the second city, Colón) into wider cosmopolitanism. Towards the end of the century, Christmas delicacies included "dulces, ron ponche ... pavos ... manzanas ... jamón", among the middle and upper classes. Before the twentieth century, for the general population, days other than Christmas were the important religious festivities (the sixth of January, for instance, or Christmas Eve - as opposed to Christmas Day proper Corpus Christi, patron saint's day, etc.), and the celebratory edibles marking these events would only exceptionally include apples, ham or turkey. (Panamanian cuisine has incorporated the following from the Chinese: chao-ping 'type of bread', chiao-tzu 'ravioli', chichen $y i$ 'steamed fish', leon pan men 'noodles', ma-fa 'toasted delicacy', mien tiao 'noodles', wan ton 'fried patties'. Also chop suey or shop suey 'finely chopped food', which means 'restaurant' as well, when it refers to the kind that serves what is considered Chinese-style food.). ${ }^{11}$

\section{Glossary}

The main aim of this paper, as pointed out from the outset, has been to consider the Caribbean English loanwords of a culinary nature in contemporary Panamanian Spanish. These are, in Spanish spelling and in alphabetical order, bieks (< English bakes), bon (< English bun), domplín (< English dumplin or dumpling), patí (< English patty), rondón (< English run down), sao (< English souse), saril (< English sorrel), uan pat (< English one pot) and yiyimbré (< English ginger bread). These words have already penetrated Panamanian Spanish with a certain measure of permanence, i.e., both terms and concepts are part of twentieth and twenty-first century Panamanian culinary culture.

The following lines focus on the origin of each term in English and refer to the term's present status in the Spanish of Panama City, the capital and main urban area of the Central American republic, from which neologisms are irradiated throughout its territory, due to well-known sociological reasons.

\section{- bieks, biex (< bakes $)$}

In the $O E D 2$, bake (s.v.) appears as a noun derived from the verb bake, and is described as a biscuit, with an eighteenth century attestation (1787, "Here's crying out for bakes and gills"). The word, common in Jamaican speech, is found in PCE, where it is usually 
used with a final -s, whether singular or plural, and has thus been transferred to Panamanian Spanish. In PCE it refers to a salt bun, not a biscuit. Thomas-Brereton (1993: s.v.) defines it as 'flour dough made into balls, flattened then fried', although she relates it to Barbados, not Jamaica. The pronunciation in PCE is either /bieks/ or /beiks/, according to the lect considered. The form bake appears in the $D C U$, which explains that in a number of areas bakes is considered a plural.

- bon $(<$ bun $)$

For the $O E D 2$ a bun (s.v.) is 'a sort of cake: the use differs greatly in different localities, but the word generally denotes in England a sweet cake (usually round) not too large to be held in the hand while being eaten. In Scotland it usually means a very rich description of cake, the substance of which is almost entirely composed of fruit and spice; the richest kind of currant bread'. In Panamanian Spanish it refers to a culinary delicacy of West Indian origin, a sweet cake, usually prepared for Easter. ThomasBrereton (1993: s.v.) considers it 'a sweet fruity bread eaten traditionally at Easter'. The Panama Cyberspace site (latter part of the twentieth century and onwards) offers buns for sale year round stressing the Caribbean origin of the foodstuff. This sort of cake has been part of the general Panamanian diet for a lengthy period. In reference to Panama City in 1935, J. Conte Porras wrote that: "En ese entonces eran famosos los dulceros que se apostaban en la Casa Miller, en donde se vendía "El Bum", "El Poni" y el "Pan Blenco" entre muchísimas otras variedades de dulce .... (1975: 88). ("Poni" is PCE "yucca pone", or simply "poon < pone, n. A kind of cake made from sweet potato or corn. [...] Also yuca pone" Thomas-Brereton 1993: s.v.).

\section{• domplín $(<$ dumpling)}

First attested for c. 1660, dumplin(g) is, for the OED2, 'a kind of pudding consisting of a mass of paste or dough, more or less globular in form, either plain and boiled, or inclosing fruit and boiled or baked'. Or 'a pasty mass like a dumpling'. ThomasBrereton's definition reads 'boiled dough made from wheat, cassava or corn flour'. The word came through Jamaican English, where it is in common use. In Panamanian Spanish, the word is stressed on the last syllable, as it is in PCE. Conte Porras (1975: 89), mentions it among the goodies that were sold by West Indians in Panama City in the 1930's: "En una larga fila dominguera acudían las gentes para comprar el arroz con coco y guandú, el bacalao con papa, el domplín, y otras especialidades". ("Bacalao con papa", i.e., codfish with potatoes, was for long considered a typical West Indian dish, as it appears in a once popular folk chant: "¿Qué comen los chombos?/ Bacalao con papa./ ¿Y en qué lo cocinan?/ En una lata." A less racist variant proposes the first line as "¿Qué comen los hombres?"; chombos is a derogatory term for those of West Indian origin). 
- patí $(<$ patty)

The form in English is an alteration of F. pâté, OF. pasté pasty, 'a little pie or pasty' with written attestations since 1710. A frequent element in Jamaican cuisine, it has been incorporated into Panamanian Spanish, although it is used along with the native form empanada, which is much more common. Pereira de Padilla (1974: s.v.) describes it thus: "empanada preparada con harina, carne y picante. Ú en Bocas del Toro. También en la provincia de Colón". The two locales mentioned are heavily populated by West Indians and their descendants. For Thomas-Brereton (1993: s.v.) it is "pastry filled with ground beef'. César Young Núñez (2005: 83) extols the West Indian empanadas patí. Higuero Morales (1993: s.v.) writes that the word is patie, 'empanada costeña'. The $-e$ of the spelling goes unpronounced.

- rondón $(<\text { run down })^{12}$

A Jamaican dish in which coconut milk and spices are essential, to which meat, seafood, fish or only vegetables may be added (see $D C U$ : s.v.). The dish, prepared in different ways, has crossed over into Panamanian mainstream culture, since coconuts are a common and popular food on the Isthmus. Araúz Monfante (2007: 177) explains that in the province of Bocas del Toro "el rondón es un plato típico de la cocina antillana que consiste en pescado, de preferencia pargo, con leche de coco, plátanos, yuca, zapallo". Pereira de Padilla (1974: s.v.) describes it as "sopa preparada con pescado, leche de coco, toda clase de verduras, especias y picante. Es un plato muy conocido en Bocas de Toro y en Colón, especialmente entre la población afroantillana".

- sao (< souse)

The OED2 considers "souse (saUs), n.1 Now chiefly dial. and U.S. Forms" to be from "OF. sous (souz, soulz, soult, = Prov. soutz, sols), or souce, ad. OHG. sulza, OS. sulta, or directly f. the Germanic stem sult- (see salt $\mathrm{v}^{1}$ and silt $\mathrm{n}$.), whence also It. solcio pickle, condiment". It refers to "various parts of a pig or other animal, esp. the feet and ears, prepared or preserved for food by means of pickling' and has attestations since the eighteenth century. A type of food common not only in Jamaica but in Barbados and Trinidad, it has grown considerably in popularity in Panamanian cuisine since the 1970's. A contemporary narrator, in his somewhat autobiographical reminiscences, on pondering the excellence of a childhood cook, lauded her with " $i$ Salud maestra .../... del saus! Esas patitas de puerco adquieren alcurnia y aroma en tus picantes" (Endara 1993: 102), the Caribbean dish incorporated among the rest, all of long standing in the non-West Indian community of Panama. Saos and saus (spelling and pronunciation) are other Panamanian Spanish adaptations of souse (see Moreno Mejías 2010: 166). 
- saril $(<$ sorrel $)$

According to the DJE, sorrel/saril/ is the common name of hibiscus sabdariffa. Its fruit /saril/ is used to make refreshing beverages. It is also called French, Indian, Jamaica(n) or red sorrel, but these names are uncommon in PCE. (In Mexico the plant is known as flor de Jamaica). Until roughly the beginning of the 1970's, in Panama the beverage was limited to the West Indian group and was produced mainly during Christmastime. Since then the drink has become popularized. Rogelio Sinán, in his 1946 short story "Todo un conflicto de sangre" mentions it as serril: "vino tenue, dulce, amoratado, que llamaban serril" (1971: 110) whereas Joaquín Beleño, another acclaimed Panamanian novelist, uses the spelling ceryl in his award-winning Curundú (1963; prized in 1956 but written in and describing the forties), in which he portrays the drink as typically West Indian and considers it an "helado vino con trozos de hielo y jenjibre" (sic) (p. 134), and with special reference to its color: "el agua en el piso es casi roja, como agua de ceryl" (p. 130). In Jamaica, "because the sorrel ripens at that season, it is a Christmas drink - appropriately, a clear, bright red liquid which is mixed with ginger and drunk unfermented or fermented. It may be strengthened with rum or wine" (Cassidy 1971: 204). The fermented or strengthened type may have led the Panamanian writers to consider it a type of wine. Other names for the beverage made from sorrel ("sorrel drink, jam, sauce, sops, soup, water") are not current in PCE. Higuero Morales (1993: s.v.) describes it as "frutilla de color rojo, de la cual se hace un refresco del mismo nombre". Moreno Mejías (2010: 157) includes the word as an Anglicism adapted to Panamanian Spanish.

This form has been attested with different spellings. According to the OED2, it comes from "OF. surele (12th cent.), sorele, surelle (mod.F. surelle), f. OF. sur adj., an adoption of the Germanic sužr sour $a$." and has been documented since the fifteenth century.

\section{- uan pat $(<$ one pot $)$}

The Spanish spelling aspires to reproduce the PCE pronunciation of the form. The meal considered is a mixture of different edibles, including meats that are all cooked in "one pot", which explains the name. Allsopp's DCU lists the form one-pot (s.v.) as of use in Grenada, St Kitts and Trinidad, and relates it to benačin, a Wolof term for a meal made by cooking many edibles together. For the overall Panamanian public, it seems to be the least popular of the types of food mentioned in this glossary.

\section{- yiyimbré (< ginger bread)}

A newspaper comment (Thalía S. Morales "Las tunas del barrio Bolívar", 2003) states that "el plato preferido era el sancocho de gallina de patio y el yiyimbré, (ginger-bread) el dulce más antiguo de la provincia de Chiriquí", which seems to give this delicacy a long-standing preference in regional cuisine, and points to its rapid adoption in the 
Republic. Before this article was published, another appeared in the La Prensa, May 25 2003, p. 6 of the printed copy. Elvia Alvarado de Amador's article ends "Como regalo les dejo una batea de dulces o "dulceros", [...] sin que en ella falte el ginger bread, o famoso "yiyimbré chiricano". Pereira de Padilla (1974: 63) includes it as a word from the Western provinces of Chiriquí and Bocas del Toro. (Revilla 1976 s.v. writes ñinibré, and proposes it as an obsolescent term of the town of Chepo, which is near the city of Panama). Evidently of Caribbean origin, and common in the Bocas del Toro province among descendants of West Indians and, also, in the southwestern province of Chiriquí - perhaps more so in the banana plantation area of Puerto Armuelles - "yiyimbré's" mating with "sancocho de gallina" tells of the blend of old and new habits in Panamanian culture. Sancocho, a chicken-based type of goulash, is an article of food of long standing in Panamanian cuisine and, as reflected in a previous quote, is considered "la culminación gustativa", the epitome of culinary taste; yiyimbré cannot be older than the nineteenth century, but has already grown into what is considered another traditional national delicacy.

\section{Conclusions}

The names of foodstuff incorporated from the English-speaking Caribbean into the general Panamanian urban diet tell of one of the traits of this Central American culture. As Rodrigo Miró, the foundational Panamanian historian and cultural observer, once established, it declares "síntesis e integración, los modos de Panamá". It would seem as if new elements are frequently admitted to the melting pot (be it culinary or metaphorical), making Panamanian culture a unique mix.

Generalization of names of Caribbean edibles points to the integration of the West Indian group to mainstream Panamanian culture. The process has been accelerated in the last years, especially due to the disappearance of the segregated, American-run area known as the Panama Canal Zone, peopled mainly by West Indians and their descendants.

Although some names of these edibles exist in the Limón Creole of Costa Rica, due to it also being an offshoot of Caribbean English, they have remained mainly limited to the descendants of West Indians: "Entre las comidas especiales figuran el rondón (arroz y pescado), el calalú (sopa con langostinos) .... Como bocaditos están el patí, bami, pan bon, (todas especialidades de Limón)" (Herzfeld 2002: 22). In Panama, however, the foodstuff has been popularized, and since at least the 1930's, has become part of the general diet, which explains the common knowledge held about them, the adaptation of forms in Panamanian Spanish and their appearance in the literature of the country. 


\section{Notes}

1. New studies have appeared after Jamieson (2004, 1993), for which, see Jamieson's forthcoming bibliographical essay, "Materials for the Study of Panamanian Creole English". Sociological research on the West Indian group in Panama can be traced throughout, but, so far, an anthology or reader is lacking.

2. See Maria Seidl's 2010 piece in the bibliography.

3. A noticeable difference between PCE and Limonese Creole can be explained by extralinguistic factors: Limon Creole was constantly refurbished by Jamaican speakers, who arrived cyclically to Costa Rica and were limited by law to one geographical area, where, more than in Panama, they were then socially segregated - by the majority Hispanic-based culture or by the Americans. PCE had a dissimilar renewal of this particular nature, and its speakers were more in overall contact with (prestigious) American English. Both varieties have been changing their lexifier language from English to their national form of Spanish. This last assertion also rings true for the Creole English spoken in Nicaragua or in the Caribbean Colombian islands of San Andrés, Santa Catalina and Providencia.

4. Italicized words are in Thomas-Brereton's "phonological" (sic) transcription; accompanying definitions are also hers

5. See Allsopp, J. (1996: 239) and DCU (s.v.), both ascertaining the word is only used in Belize.

6. See Heckadon Moreno (1975) on the sociological implications of this word in Panama City.

7. Other derivatives of batty in the Spanish from the city of Colón are batifulona and batisucia, both derogative. They are documented in Revilla (1982).

8. Joaquín Beleño, Rafael Pernett y Morales, Tristán Solarte and César Young Núñez are other Panamanian writers of renown who have included PCE terms in their literature.

9. Panamanian novelist Antonio Moscoso B.'s 1961 volume, Buchí (Bushman), lends literary hierarchy to the word.

10. Adherents of the religious movement speak of "Spirit Church".

11. See E. Chong Ruiz's 1993 volume on the Chinese influence on Panamanian culture.

12. It is also spelled rungdung. Run down seems to refer to the simmering down of coconut juice in making the dish.

\section{References}

Aguilera Patiño, Luisita (not dated) [1948?]: El panameño visto a través de su lenguaje. Panama: Ferguson \& Ferguson.

Allsopp, Jeannette (1996): "Spanish loanwords in Caribbean English". Félix Rodríguez González (ed.), Spanish Loanwords in the English Language. A Tendency towards Hegemony Reversal. Berlin-New York: Mouton de Gruyter. 253-268.

Allsopp, Richard, ed. (1996): Dictionary of Caribbean English Usage. Oxford: Oxford UP.

Alvarado de Amador, Elvia (2003): "Comidas y postres chiricanos". La Prensa, May 25 2003, p. 6.

Araúz Monfante, Celestino Andrés (2007): Bocas del Toro y el Caribe Occidental: Periferia y marginalidad siglos XVI-XIX. Panama: Mariano Arosemena.

Beleño, Joaquín (1963): Curundú. Panama: Ministerio de Educación. 
Cassidy, Frederic G. (1971): Jamaica Talk. Three Hundred Years of the English Language in Jamaica. London: Institute of Jamaica-Macmillan.

Cassidy, F.G. and R.B. Le Page, eds. (1967): Dictionary of Jamaican English. Cambridge: Cambridge UP. [There is a second edition.]

Cedeño Cenci, Diógenes (1960): El idioma nacional y las causas de su degeneración en la provincia de Bocas del Toro. Panama: Imprenta de la Academia. Also in 1960 Revista Lotería [Panama] 54: 92-128. [Place names on pages 117-120 and 122.]

Chong Ruiz, Eustorgio (1993): Los chinos en la sociedad panameña. Panama: INAC.

Conte Porras, Jorge (1975): "Suplemento. Nuestra ciudad de Panamá en el 1935". Revista Lotería [Panama] 234: 81-109.

$D C U=$ Allsopp, Richard, ed. (1996).

$D J E=$ Cassidy, F.G. and R.B. Le Page, eds. (1967).

Edwards, Jay (1974): "African Influences on the English of San Andrés Island, Colombia". In David DeCamp and Ian F. Hancock, eds., Pidgins and Creoles: Current Trends and Prospects. Washington: Georgetown UP. 1-26.

Endara, Ernesto (1993): “El fogón de doña Gume”. In his Las aventuras de Piti Mini. Panama: Manfer.

Heckadon Moreno, Stanley (1975): "Pasiero: un tipo de relación social de la capital”. Revista Nacional de Cultura [Panama] 1, 1: 9-13.

Herzfeld, Anita (2002): Mekatelyuw. La lengua criolla. San José: U. de Costa Rica.

Higuero Morales, Arnoldo (1993): Diccionario de términos panameños. Chicago: Allied Enterprises.

Isaza Calderón, Baltasar and Ricardo J. Alfaro (1968): Panameñismos. 2nd ed. rev. and enl. Panama: Academia Panameña de la Lengua.

Jamieson, Martín (2004): "Hacia la historia de la lingüística en Panamá". In Comisión Universitaria del Centenario de la República, eds., Panamá, cien años de República. Panama: MANFER. 171-183.

- (1993): “The English Creole Spoken in Panama: A Bibliography”. Revista Alicantina de Estudios Ingleses, 6: 219-221.

Justavino, Nilsa Esther (1975): West Indian English Dialects in Panama: A Historical, Social, and Linguistic Analysis. Unpublished M.A. paper, U de Panamá, Panama.

Morales, Thalía S. (2003): "Las tunas del barrio Bolívar". La Prensa Web, November 282003.

OED2 = Oxford English Dictionary. (1989). 2nd ed. Oxford: Oxford UP.

Pereira de Padilla, Joaquina (not dated) [1974]: El léxico de la región occidental de Panamá, provincias de Chiriquí y Bocas del Toro. [Panama]: no press mentioned.

Moreno Mejías, Francisco (2010): La herramienta más usada. Algunas consideraciones sobre nuestro idioma. Panama: Imprenta Articsa.

Porcell, Néstor (1976): "El efecto de demostración de la Zona del Canal sobre la sociedad panameña". In his Retorno al Principio. Panama: EUPAN. 7-25.

Quesada Pacheco, Miguel A. (1996): Nuevo diccionario de costarriqueñismos. 2nd ed. Cartago (C.R.): Tecnológica de Costa Rica.

Revilla, Ángel (1982): Lenguaje popular panameño. Panama: USMA. (1976): Panameñismos. Panama: Impresora Roysa.

Seidl, Maria (2010): Sprachen und Sprachenpolitik in Panama. Status, Prestige und kommunikativer Wert in einer mehrsprachigen Gessellschaft am Beispiel des Kuna, des Englischen und der chinesischen Sprachen, M.A. thesis, Vienna, University of Vienna, 
2010, <http://othes.univie.ac.at/8797/1/2010-03-01_0306392.pdf>. (Accessed 12 Oct. 2010).

Sinán, Rogelio (1971): Cuentos de Rogelio Sinán. San José: EDUCA.

Thomas[-]Brereton, Leticia C. (1993): Dictionary of Panamanian English. New York: Graphicart.

- (2001): "Afro-Antillean Language and Culture in Panama". In Bridget Van GronigenWarren and Melva Lowe de Goodin, eds., Afro-American Cultural Identity in Language and Culture. Panama: Sibauste. 74-78.

Young Núñez, César (2005): Crónicas de rutina. Caracas: Miro Popic Editor.

\section{Appendix}

\section{HISPANISMS IN PANAMANIAN CREOLE ENGLISH}

(According to Leticia C. Thomas-Brereton's Dictionary of Panamanian English. The author has opted for a type of phonological transcription).

aparador. China cabinet.

banda. Musical band.

baño. Special bath prescribed by a healer or obeah practitioner.

baríada. Residential community.

basí. To make fun of someone.

basilón. Fun.

batida. Refers to a police action, very common in Panamá City in the past, to pick up minors on the street after a given hour at night.

besiina. Neighbor, especially of Spanish descent.

biíbo. One who constantly tries to outsmart others.

biril. A variety of bread.

biyetero/a. One who sells lottery tickets.

bodega. Liquor store.

boío. Thatched roof house, now found at places of recreation for shelter.

bomb(i)ero. A firefighter, pertaining to firefighters.

bote. A free ride in a motor vehicle.

boteya. One who receives pay for performing little or no work, a non-existent job for which one is paid.

chalet. Single level one family house.

chayote. The fruit of the 'sechium edule' eaten as a vegetable, also known as choocho.

chiicha. A drink made from fresh fruit.

chicharóng. Deep fried pork rind.

chichipáti. Cheap, of poor quality.

chichóng. Bump on the head, especially a temporary bump after a blow.

chiva. A small wooden bus, also called by its diminutive chivita.

cholo/a. Term which designates a person of obvious Indigenous ancestry.

chombo/a. Term which designates a person of Antillean descent.

dairekshan. Address, principal's office. 
difén. Used with a reflexive pronoun with the meaning of to be able to. To be proficient at something.

di(s)ke. Used as other creoles use 'se' as a complementizer after verbs of saying, thinking or believing and before quotations.

direksión. School principal's office.

diskóshan. Argument.

duuro. Flavored ices frozen in small cups or ice cube trays.

eskoviich. Pickled fish, also known as skabiich fish.

fantasia. Costume jewelry.

fiesta. Party.

flauta. A variety of bread.

fritura. Fried foods such as yuca, carimañolas, patacones, hojaldas, etc.

gólpe. Blow, misfortune.

goma. Hangover.

gríngo. Appellative for a person from the United States, not necessarily a contemptuous term.

guacho. Children's game of throwing sticks in the mud. Also soupy meal made of rice, meat and vegetables.

guaná. Large green edible lizard.

guandú. Peas from the Cajanus Cajan, also known as gungu peas or pigeon peas in the Caribbean.

intiiria. The countryside, places north of Panama City.

kabanga. The blues.

kaarchi. A siren or whistle blown as a warning.

$k a a(r) n a v a ́ l$. The four days preceding Lent, celebrated in the streets of the city with dancing bands, masquerades, etc.

kaa(r)navaliito. Little Carnaval. Celebration in the City of Colón the week-end after Carnaval.

kamarón. Short term, temporary job.

kapatás. Overseer, foreman.

karimañola. Deep fried yucca dough filled with beef.

karnét. Identification card.

kasaesita. Legal house of prostitution.

kesekuando. This and that, and so on.

komádre. Term of address used for females in a parent-godparent relationship.

kómics. Animated drawings, cartoons.

kompádre. Term of address used for males in a parent-godparent relationship.

kompársa. Dancing band in the Carnaval celebration.

konhunto. Folkloric dance troupe.

konkolón. Rice that remains stuck to the bottom of the pot, considered a delicacy.

konsehal. Council representative.

korrejiduría. Community court-house.

kriol, krioyola. Term which designates people of Antillean descent in Panamá.

kuartel. Police precinct.

kuatí. Coin no longer in circulation worth one quarter of five cents. Now used in reference to something of little or no value.

kupo. Available space.

kuskús. Applied to curly or kinky hair.

kuuna. One of the indigenous peoples of Panama. 
la lata. Children's game of hide and go seek in which a can is used as warning.

la queda. Children's game of "it".

la tiene. Children's game of "it".

laka-laka. Talkative.

laopé. Boy.

lookó. Appellative for males, guy.

machét. Cutlass.

machí. Name used for one of the indigenous peoples of Panamá. Kuuna.

machín. Children's game.

maliant (e). Hoodlum.

mámi. Term of endearment for females.

mamí. Term of address for older women.

mangotín. A variety of plum also called jew plum.

marikóng. Homosexual.

medio-medio. Half and half, so-so, not very good, not very well.

miicha bred. A variety of bread.

mirón-mirón. Children's game.

nicolás. Term for someone who partakes of a meal and departs soon after.

no. Tag question: "isn't it?", "will you?"

nout. Grade on a test or report card.

novela. Soap opera.

ñampí. One of the edible roots.

ñap. Of little or low value. Coin no longer in circulation worth half of five cents.

$o$. Sometimes used in place of 'or' when expressing choices.

ohalda. Fried flour dough, often eaten for breakfast.

pab. To cut classes, to play hooky.

pachiita. Small flask of liquor.

palanka. Someone with influence who obtains jobs or political favors.

paleta. Frozen flavored ice on a stick.

panadería. Bread bakery.

paña. Contemptuous used for persons of Spanish descent.

pápas, in the. Well provided for, having plenty.

papaya. Fruit of the Carica papaya, known elsewhere as paw-paw but, known as papaya in the U.S.

pápi. Term of endearment for males.

patacon(es). Slices of fried green plantains.

pecho. Bony part of beef used for soup.

pesao. Cool, pretty. Said of an individual who is considered a ladies' man.

pesuña. Something more given by the seller.

piíva. Small, red or orange fruit of a palm tree. Must be boiled to be eaten.

pilinki. Stingy.

piropo. Expression used by a man to compliment a woman or to get her attention.

platillo. Bottle cap.

poyera. Panamanian national dress.

preké. Trouble, quarrel, problem, disturbance.

primaria. Elementary school.

pulpo. A hard worker. Someone who holds many different jobs. 
rapaduuro. Cake of hardened cane sugar wrapped in banana leaves. Used for sweetening drinks.

raspao. Syrup over a cone of shaved ice sometimes served with honey and condensed milk topping.

rekao berde. Fresh herbs and vegetables used for seasoning foods.

rekreo. School recess.

repelá. To reprimand.

representante. Elected community representative.

re(s)baloso. Man covered with greased-based paint who goes around town scaring people during the carnival celebration.

salida. Dismissal time, after school.

salt. To have bad luck.

sarao. Dance held in the afternoon.

sédula. Government issued personal identification card.

sekundaria. Secondary or high school.

seguuro. Government administered medical and retirement benefits.

sérvis. Toilet.

skabiish fish. Pickled fish.

supermercado. Supermarket.

tachuela. Thumb tack.

tamal(es). Steamed ground corn, stuffed with chicken or pork and wrapped in banana leaves.

tarea. Homework.

téso. Tough, said of an individual who doesn't back down from a challenge or confrontation.

toldo. Temporary dance hall, especially during Carnaval celebrations.

tortilla. Deep-fried ground corn patties.

trompo. Top.

tulibieha. Female ghost character of Panamanian folklore.

webao. Foolish, stupid.

webo-webo. By all means, without any regard for consequences, stubbornly.

$y a$. Used preverbally as an indicator of completeness.

yes. Used before verbs to provide emphasis.

yuuká. Cassava root. 